\title{
Simulating the Occurrence of the Last Sapropel Event (S1): Mediterranean Basin Ocean Dynamics Simulations Using Nd Isotopic Composition Modeling
}

\author{
T. Vadsaria1, G. Ramstein1, J-C. Dutay1, L. Li2, M. Ayache3, and C. Richon4 \\ 1Laboratoire des Sciences du Climat et de l'Enrivonnement, Gif-sur-Yvette, France \\ 2Laboratoire de Météorologie Dynamique, Paris, France \\ 3Environnements et Paléoenvironnements Océaniques et Continentaux, Pessac, France \\ 4School of Environmental Sciences, University of Liverpool, Liverpool, United Kingdom
}

\section{Key Points:}

- High-resolution numerical modeling of environment of deposition of Sapropel S1

- Nile river outflow enhancement triggers important changes in oceanic circulation

- Boundary exchanges $\varepsilon N d$ modeling depicts reduced circulation, and records for S1 show a similar anomaly

Corresponding author: Tristan Vadsaria, tristan.vadsaria@1sce.ipsl.fr 


\section{Abstract}

Sapropels are sediments rich in black, pelagic organic matter which occur mainly in the Eastern Mediterranean, documenting anoxic environments and high biological productivity. The quasiperiodicity of deposition of sapropels - over millions of years - relates to the Earth's precession cycle, which directly enhances the African monsoon, ultimately increasing freshwater input from the Nile. The last sapropel event, S1, occurred about 10,000 years ago (Early Holocene), when the Mediterranean region was warmer and wetter than today. Several modeling studies reflect the impact of this climate and a stronger Nile influx on Mediterranean oceanic circulation, but the regional models used lacked the spatial resolution necessary to simulate winter intermediate and deep convection. Here, we investigate recently occurring changes in the convective areas in the Eastern Mediterranean, using a regional oceanatmosphere coupled climate model of high spatial resolution, essential to the simulation of a realistic Mediterranean circulation for present-day conditions. We focused on the thermohaline circulation and the simulation of neodymium isotopic composition to compare our modeling results to modern data and paleo-proxies. A sensitivity experiment shows a radical response of the Mediterranean to enhanced Nile discharge, creating the appropriate conditions for sapropel formation. We thus demonstrate that increased discharge of the Nile River can trigger the shutdown of Eastern Mediterranean convection and create conditions favorable to the development of anoxic events. 


\section{Introduction}

Since the closure of the East Tethys seaway 14 million years ago (Hamon et al. [2013]), the only connection between the Mediterranean and the global ocean is the Strait of Gibraltar. This enclosed configuration has created favorable conditions for the development of sapropel events, i.e. anoxic conditions. The properties of sapropel events (strength, extension, duration) vary over time (see Rohling et al. [2015] for a review). The last event (S1) took place 10,000 years ago, is the best documented, and subject of a large body of research (both observations and modeling). Rossignol-Strick et al. [1982], in their pioneering study, found that the occurrence of sapropels was correlated with orbital forcing. They hypothesized that orbital parameters can strongly modulate the African monsoon, and therefore drastically influence the freshwater input in the eastern part of the Mediterranean Sea. However, how physical mechanisms at orbital frequencies affect the ocean is not clearly understood. The changes in ocean dynamics (e.g., seawater convection in winter) and in biogeochemistry (e.g., consumption of oxygen) induced by changes in freshwater inputs are major issues. To better understand these issues, we used a high-resolution coupled ocean-atmosphere model to accurately represent convection in the Mediterranean Sea. Nd is a rare earth element commonly used as a tracer of water masses, and $\mathrm{Nd}$ data have been used in recent reconstructions to gain information on changes in circulation during S1 sapropel deposition (Dubois-Dauphin et al. [2016], Cornuault et al. [2018]). We simulated the neodymium (Nd) isotopic composition in Mediterranean Sea waters (Ayache et al. [2016]) to evaluate our modeling studies.

\subsection{The sapropels}

Sapropel events have been described and investigated since they were first identified in the middle of the $20^{\text {th }}$ century (Kullenberg [1952]). These events, occurring quasi-periodically with a frequency of about 21,000 years, are specific to the Mediterranean Sea. They have been recorded over the last 13.5 million years, i.e., since the closure of the East-Tethys Sea (Hamon et al. [2013]), with an interruption during the Messinian Salinity Crisis (Suc [1984]). For the last 5 million years, these events can be clearly identified in marine sediments. They are characterized by an organic-rich layer of sedimentation, and found mainly in the eastern basin. Sapropel sedimentation occurred in an anoxic environment allowing organic matter to be preserved, due to the shutdown of thermohaline ventilation which allows oxygenation (Sachs and Repeta [1999], Möbius et al. [2010]) and/or enhanced biological productivity leading to increased oxygen consumption (Calvert et al. [1992], Martinez-Ruiz et al. [2000]). 
One of the major mechanisms invoked as a trigger of sapropel events is the intensification of the African monsoon, which would explain the correlation between the occurrence of sapropels and insolation variation due to precession (Emeis et al. [2003], Larrasoaña et al. [2013]). Since the pioneering study of Rossignol-Strick et al. [1982] found a relationship between sapropel occurrences and precession cycles, many studies have tried to quantify this causal link. The large amount of geological evidence (Calvert et al. [1992], Kallel et al. [1997], Kallel et al. [2000], Krom et al. [1999], Demenocal et al. [2000], Martinez-Ruiz et al. [2000], Emeis et al. [2003], Kuhnt et al. [2007], Siani et al. [2013], Revel et al. [2014], Hennekam et al. [2014], Tachikawa et al. [2015], Grant et al. [2016]) provided constraints and a useful basis to build quantified scenarios to explore the causes of sapropel deposition (Rohling and Hilgen [1991], Bethoux [1993], Rohling [1994], Cramp and O'Sullivan [1999], Casford et al. [2003], De Lange et al. [2008], Schmiedl et al. [2010], Rohling et al. [2015]). Numerical modeling proved to be efficient in the reconstruction of dynamic and biological conditions compatible with sapropel formation (Myers et al. [1998]], Stratford et al. [2000], Myers and Rohling [2000], Myers [2002], Bianchi et al. [2006], Meijer and Tuenter [2007], Meijer and Dijkstra [2009]).

Recent modeling studies (Adloff et al. [2011], Grimm [2012], Grimm et al. [2015]) aimed to simulate the $\mathrm{S} 1$ event from its onset. Using an oceanic model with a carbon cycle at a spatial resolution of $14^{\circ}$, they found that enhanced Nile runoff could not trigger the necessary anoxic conditions to form sapropel. A more specific scenario, involving preconditioning of the cold and low salinity water coming from the last Heinrich event, was suggested to be needed to explain S1 formation.

The aim of this paper is to revisit the issue of the sensitivity of an AORCM (AtmosphericOcean Regional Circulation Model) to an increase in Nile freshwater through hosing experiments, at a higher spatial resolution of the regional Mediterranean Sea model $\left(1 / 8^{\circ}\right)$ than previous investigations. Changes in ocean dynamics caused by inputs of freshwater are crucial to trigger sapropel formation, and the increased resolution allows better simulation of the formation of intermediate and deep waters in winter (Somot et al. [2006], Beuvier et al. [2010], Adloff et al. [2015]). With Nd isotopic composition incorporated in our modeling system, our main goal is to assess the abrupt shutdown of Mediterranean Thermohaline Circulation (MTC) in comparison to recently retrieved data in the Mediterranean Sea. We also want to show the potential of $\mathrm{Nd}$ as a tracer to reveal changes of the oceanic dynamics.

\subsection{New constraints on Mediterranean Ocean dynamics}


$\mathrm{Nd}$ is a rare earth element with seven isotopes. In oceanic waters, its main source is from continental margin sediments and their exchange with adjacent seawater, known as boundary exchange (BE) (Tachikawa et al. [2004], Arsouze et al. [2007]). Other minor sources for ocean waters are discharges from rivers and Aeolian dust deposition. The Neodymium Isotopic Composition (NIC) is expressed as $\varepsilon N d, \varepsilon N d=\left(\left(\mathrm{Nd}^{143} / \mathrm{Nd}^{144}\right)\right.$ sample/( $\left.\left.\mathrm{Nd}^{143} / \mathrm{Nd}^{144}\right) \mathrm{CHUR}-1\right) \mathrm{x}$ 10000, where CHUR is the CHondritic Uniform Reservoir, related to the present day average value for the Earth surface, $\left.\mathrm{Nd}^{143} / \mathrm{Nd}^{144}\right) \mathrm{CHUR}=0.512638$; Jacobsen and Wasserburg [1980].

$\varepsilon N d$ behaves quasi-conservatively in open ocean, when far from lithogenic sources. This characteristic allows for the tagging of water masses, and $\varepsilon \mathrm{Nd}$ is commonly used as a tracer of water masses for oceanic circulation in past and present (Lacan and Jeandel [2005], Frank [2002], Piotrowski et al. [2004], Arsouze et al. [2008]).

In the context of sapropel events, $\varepsilon N d$ is an appropriate tracer of circulation in the Mediterranean, and $\varepsilon N d$ in marine sediments and cold-water corals allows the identification of the freshwater supply in the sediment material, as suggested by Freydier et al. [2001], Scrivner et al. [2004] and Revel et al. [2014] for the Nile River. The continental margin in the Mediterranean region is characterized by a strong west-east NIC gradient (Figure 1), which is observed in its modern distribution (Tachikawa et al. [2004], Vance et al. [2004], Henry et al. [1994]). Coral data from the Sardinia Channel suggest a reduction of the Levantine Intermediate Water (LIW) circulation (Dubois-Dauphin et al. [2016]) during the formation of the S1 sapropel. Cornuault et al. [2018] find distinctly different pattern in the WMS (Western Mediterranean Sea) and the EMS (Eastern Mediterranean Sea) in their observations at the Sicily-Tunisian Strait and in the Levantine basin.

\subsection{Outline of the paper}

In this paper, we re-investigate the hypothesis that increased influx from the Nile River could have caused sapropel formation, using a higher resolution model (1/8_) of the Mediterranean Sea than previous studies, which allows us to better simulate winter intermediate and deep convection. We used a regional ocean-atmosphere coupled model, including a simulation of $\varepsilon N d$ distribution, which provides a new constraint on and insight into oceanic circulation. The development of an appropriate tool coupling ocean and atmosphere at high-resolution and including tracers (such as $\varepsilon \mathrm{Nd}$ ) allows us to correctly depict the present day circulation, and to quantify the causal link between changes in insolation and stratification in the eastern basin. However, our high spatial resolution simulations with a complex platform coupling ocean, 
atmosphere and biogeochemical models only analyses the triggering of S1, for hundreds of years. At this stage, we are not able to conduct coupled simulations of long duration, but we demonstrate that the response in ocean dynamics creates favorable conditions for the occurrence of anoxic events. We do not aim to simulate sapropel S1 from its onset to the end of its deposit, because our model setup does not take into account major forcing needed to develop anoxic environments leading to the S1 deposit (e.g., sea level rise).

\section{Materials and Methods}

We used a coupled ocean-atmosphere regional modeling platform to investigate the impact of a freshwater perturbation on the dynamics and the associated impact on the eNd distribution in the Mediterranean.

\subsection{The regional ocean-atmosphere coupled model}

The regional model LMDz4-NEMOMED8 was used by L'Hévéder et al. [2013] in their investigation of the interannual variability of deep convection in the Northwestern Mediterranean Sea. We selected this coupled modeling platform for the present study because it can capture the formation of deep water masses in the Mediterranean Sea. The ocean model NEMOMED8 (Beuvier et al. [2010]) is the regional configuration of the NEMO global ocean modeling platform (Madec [2008]) for the Mediterranean basin. It includes a buffer zone in the Atlantic Ocean from the Strait of Gibraltar to $11^{\circ} \mathrm{W}$, which serves as a boundary for the Mediterranean Sea. Both temperature and salinity are relaxed to observed climatology in the Atlantic Ocean. The horizontal resolution is $1 / 8^{\circ}$ in longitude and $1 / 8^{\circ} \cos \varphi(\varphi$ is the latitude), corresponding to a range of $9 \mathrm{~km}$ to $12 \mathrm{~km}$ from the north to the south. The grid is stretched and tilted at the Gibraltar Strait to properly represent the NW-SE axis of the strait, so that the local resolution is increased to $6 \mathrm{~km}$. The model has 43 vertical layers of inhomogeneous thickness (from $6 \mathrm{~m}$ at the surface to $200 \mathrm{~m}$ at the bottom). The model explicitly represents 33 river mouths. The Black Sea, with its net hydrological balance, is considered as a river flowing into the Aegean basin. NEMOMED8 has been used to assess mechanisms controlling the interannual variability in the Mediterranean Sea, such as the Eastern Mediterranean Transient event ("EMT") when the formation of deep water in the eastern basin moved from the Adriatic basin to the Aegean basin (Beuvier et al. [2010], Béranger et al. [2010]). LMDz4-regional (Li et al. [2012]) is a regional configuration of the global atmospheric general circulation model LMDz4 (Hourdin et al. [2006]). Its spatial resolution is about $35 \mathrm{~km}$ over the Mediterranean, and IT becomes rapidly coarser outside this region. It has 19 vertical layers. As outlined in 
L'Hévéder et al. [2013], the behavior of the LMDZ4-regional is free to evolve in the Mediterranean domain but is restored to ERA-Interim reanalysis beyond the region. The oceanic and atmospheric components are interactively coupled to each other through the OASIS3 coupler, with a daily coupling frequency.

\subsection{The Neodymium component}

The neodymium tracer is implemented in the NEMO model following the approach proposed by Ayache et al. [2016]. It takes into consideration only the main source of $\mathrm{Nd}$ in the ocean, i.e., the boundary exchange $(\mathrm{BE})$ with the continental margins representing the major source of $\mathrm{Nd}$ on the global scale (Arsouze [2007], Rempfer et al. [2011]). About 90\% of the total input comes from boundary exchange, and the contribution from dust and rivers is marginal in the upper ocean (1500m), (Arsouze et al. [2009]). This simplified approach allows the general characteristics of the global $\varepsilon \mathrm{Nd}$ distribution to be represented in the Mediterranean basin [Ayache et al. , 2016], even if the reconstructed isotopic distribution is too radiogenic due to the consideration of the boundary exchange only. The eNd modeling can be used to provide information on the response of a transient event such as the EMT event. Although including dust deposition slightly improves the $\varepsilon N d$ seawater simulation, the exclusion of dust from the current version of our modeling platform is justified by the fact that data and model cannot constraint the Mediterranean Sea at high resolution for the dust, and also because the wetter conditions in northern Africa, during the Early Holocene, probably changed the dust input from the Sahara. This simplified modeling approach has also been used in paleoclimatic studies to investigate global oceanic circulation during the Last Glacial Maximum (LGM) (Arsouze et al. [2008]), as well as the shoaling of the American Seaway during the Miocene (Sepulchre et al. [2014]). In the model, $\varepsilon \mathrm{Nd}$ is implemented as a passive tracer which does not affect ocean circulation. Transport is by advection and diffusion, since BE is the only source considered. BE is parameterized by a relaxation equation of the isotopic composition of the continental margin.

$$
S(\varepsilon N d)=\frac{1}{\tau}(\varepsilon N d \text { margin }-\varepsilon N d) . \text { maskmargin (Arsouze et al., 2007) }
$$

The relaxing time in the Mediterranean Sea is 3 months (Ayache et al. [2016]). The Nd composition of the continental margin, $\varepsilon N d$ margin, is prescribed from a high resolution map [Ayache et al. , 2016] and is upscaled to the NEMOMED8 resolution (Figure1). The maskmargin is the percentage of continental margin in the grid box. 


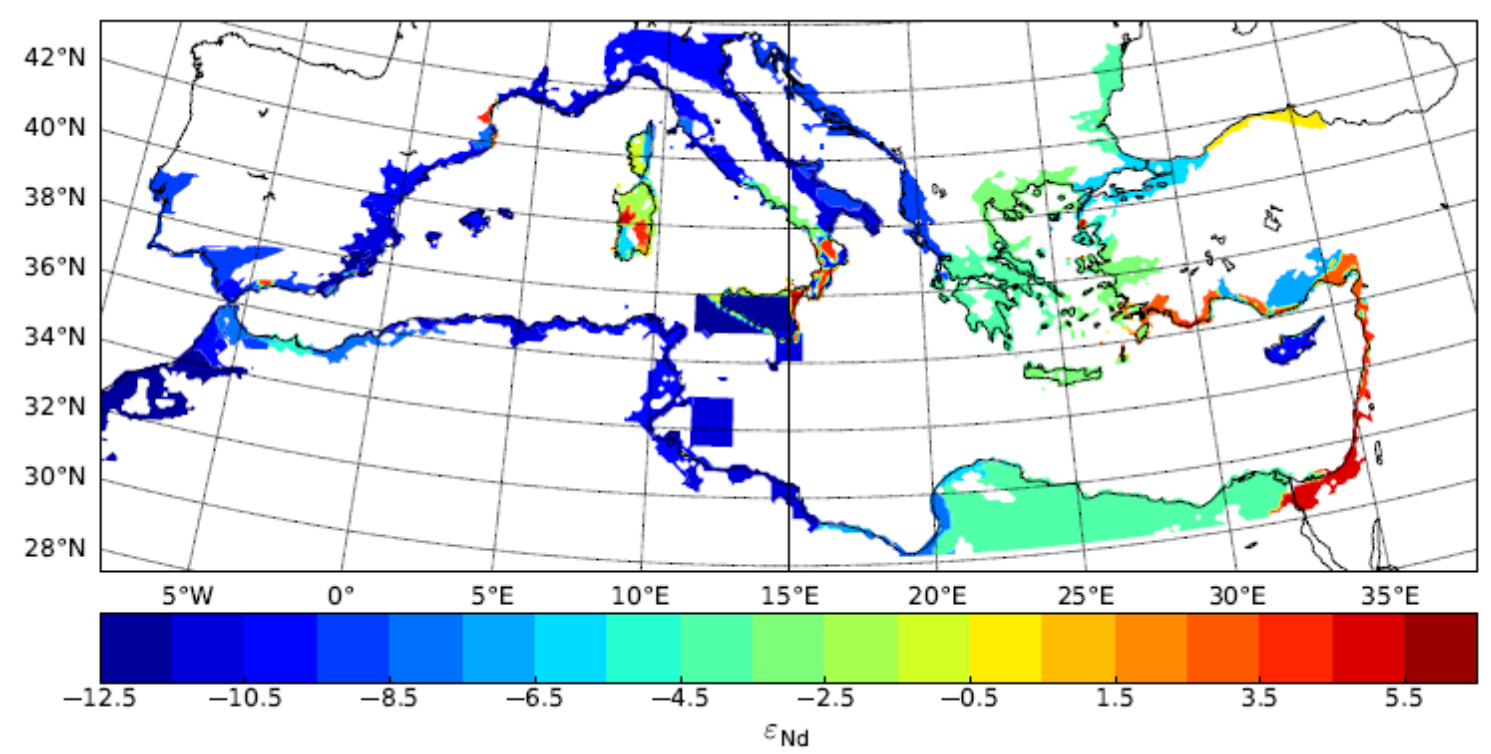

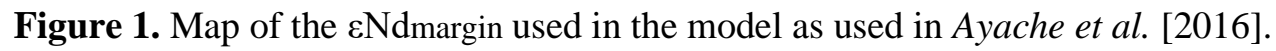

\subsection{Experimental design and external forcing}

We performed two major experiments with the AORCM. One simulated the pre-industrial state of the Mediterranean (CTRL) whereas the second focused on the impact of a freshwater perturbation from the Nile (5NILE). The Nile water discharge in the control experiment is set at $2930 \mathrm{~m}^{3} \cdot \mathrm{s}^{-1}$, the average amount estimated before the construction of the Aswan dam, according to the RivDIS database (Vorosmarty et al. [1998]). For the hosing experiment, a supplementary runoff of $12000 \mathrm{~m}^{3} \cdot \mathrm{s}^{-1}$ was added to the pre-dam value, giving a rough total of $15000 \mathrm{~m}^{3} \cdot \mathrm{s}^{-1}$ (5NILE). This estimate has been derived from the PMIP2 (Braconnot et al. [2007]) global simulation during the early Holocene, showing an enhanced African monsoon and an increase in the Nile outflow. This estimate of the Nile discharge is close to that used in Adloff [2011] and Grimm et al. [2015]. The outputs from other Mediterranean rivers are based on modern values from Ludwig et al. [2009]; the Black Sea is treated as a river flowing into the Aegean Sea. The Atlantic buffer zone is relaxed to the climatological observed water temperature and salinity from Levitus [1983] The atmospheric model is driven by ERA-interim reanalysis. The relaxing time scale is 10 days inside the Mediterranean domain, and half an hour outside. The nudged variables include meridional wind, zonal wind, temperature and humidity at 6 hours intervals. In order to avoid introducing the current anthropogenic climate change trend into the simulations, we first formed a set of atmospheric forcing for randomly selected years between 1979 and 1989. The same sequence was used in both AORCM simulations. There is no special treatment when moving from December of one year to January of the following year. The duration of both the CTRL and 5NILE simulations is 90 years. The 
neodymium configuration used the exchange with the continental margin as the boundary condition and the main source of $\mathrm{Nd}$ (Figure 1). In the Atlantic buffer zone, $\varepsilon \mathrm{Nd}$ values are defined from observations using the NE Atl. MED-15 vertical profile from Spivack and Wasserburg [1988]. The 90 years of $\varepsilon N d$ simulations, based on the CTRL and 5NILE ocean dynamics, seem long enough for the model to reach an equilibrium state (see Supporting Information, Figure 1).

\section{Results}

\subsection{Present day circulation and convection in Mediterranean Sea}

\subsubsection{Mean Characteristics}

We first examine the vertical convection of the water column using the stratification index, corresponding to the vertical integration of the Brunt-Väisälä frequency. It varies in response to the temporal integration of the surface buoyancy flux (Somot et al. [2006], Beuvier et al. [2010]), Adloff et al. [2011], Adloff et al. [2015]. IS (index of stratification) (in $\mathrm{m}^{2} . \mathrm{s}^{-2}$ ) can be formally calculated at each model grid $(\mathrm{x}, \mathrm{y})$, for a given depth $\mathrm{h}$ as follows:

$$
I S(x, y, h)=\int_{0}^{h} N^{2}(x, y) z d z
$$

This index is a proxy for convection inhibition: when it is low, convection is more likely to occur. In this study, as in Adloff et al. [2015], the maximum depth, h, is set as the bottom, or as $1000 \mathrm{~m}$ when the depth is greater than $1000 \mathrm{~m}$. Figure 2 shows the IS from MEDATLAS II for JFM (January-February-March) and the counterpart from CTRL. The model produces a realistic IS pattern compared to MEDATLAS, showing the same regions of intermediate and deep convection, located in the Levantine basin, Aegean Sea, Adriatic Sea and the Gulf of Lion of the IS calculation). However, simulated convective regions are more extensive than in observations. 


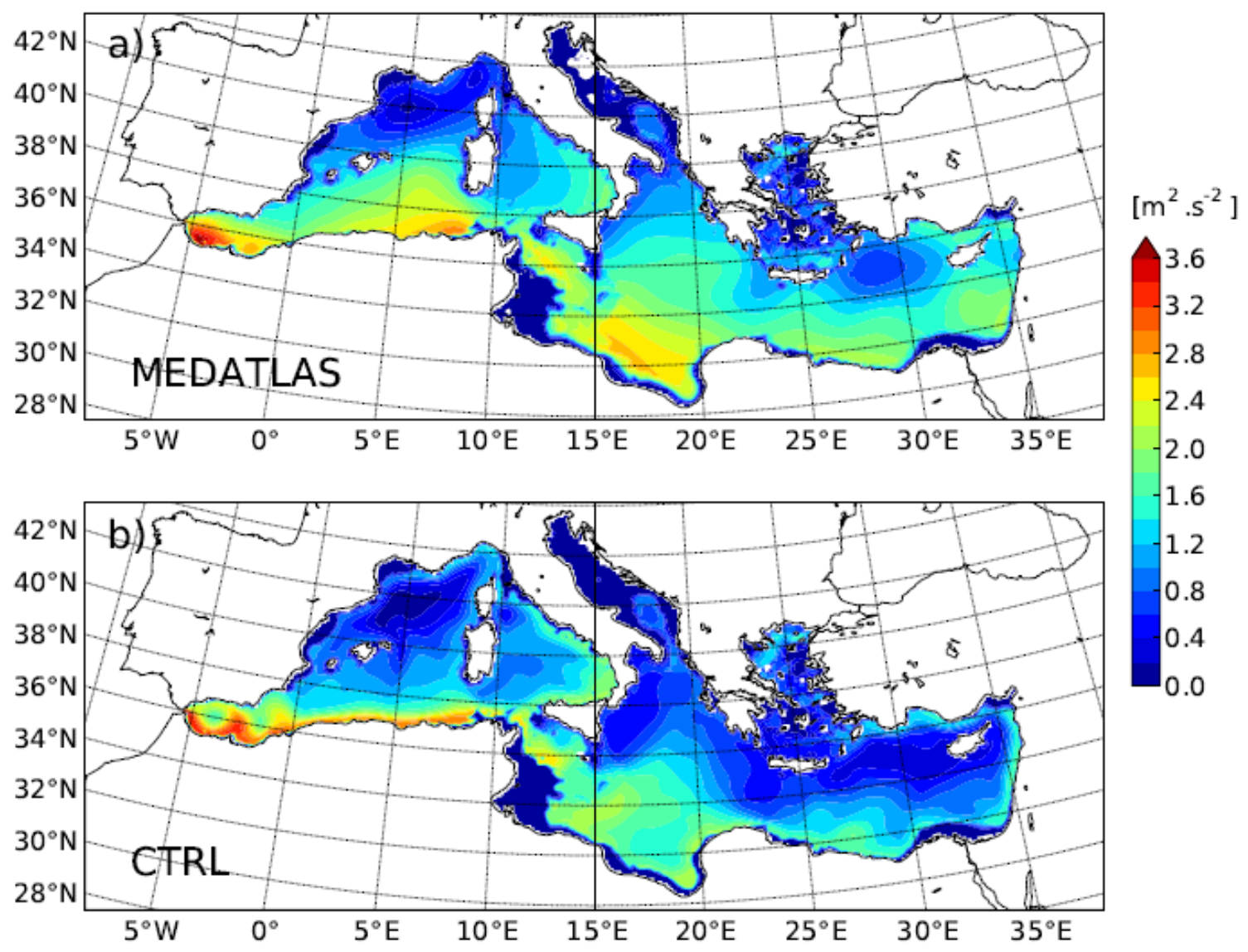

Figure 2. Index of stratification (IS, $\mathrm{m}^{2} . \mathrm{s}^{-2}$ ) during winter represented for a) MEDATLAS-II climatology and b) CTRL (averaged over the entire simulation).

249 The model is also able to simulate a realistic distribution of the mixed layer depth (MLD, Figure 3). Intermediate and deep convection areas simulated in the Gulf of Lion and in the Adriatic Sea correspond to the those observed in the MLD climatology of Houpert et al. [2015].

252 However, in the eastern basin, the convection generated by the model is overestimated in the 253 Cretan Sea and in the North Levantine basin. Furthermore, the model tends to overestimate 254 the overall depth of convection. The simulated average depth in the Gulf of Lion is larger than $400 \mathrm{~m}$ versus an average observed depth of about 300m (Houpert et al. [2015], with simulated and observed depths of $350 \mathrm{~m}$ and $200 \mathrm{~m}$, respectively in the Adriatic Sea and of $240 \mathrm{~m}$ and $150 \mathrm{~m}$, respectively in the Cretan Sea. 

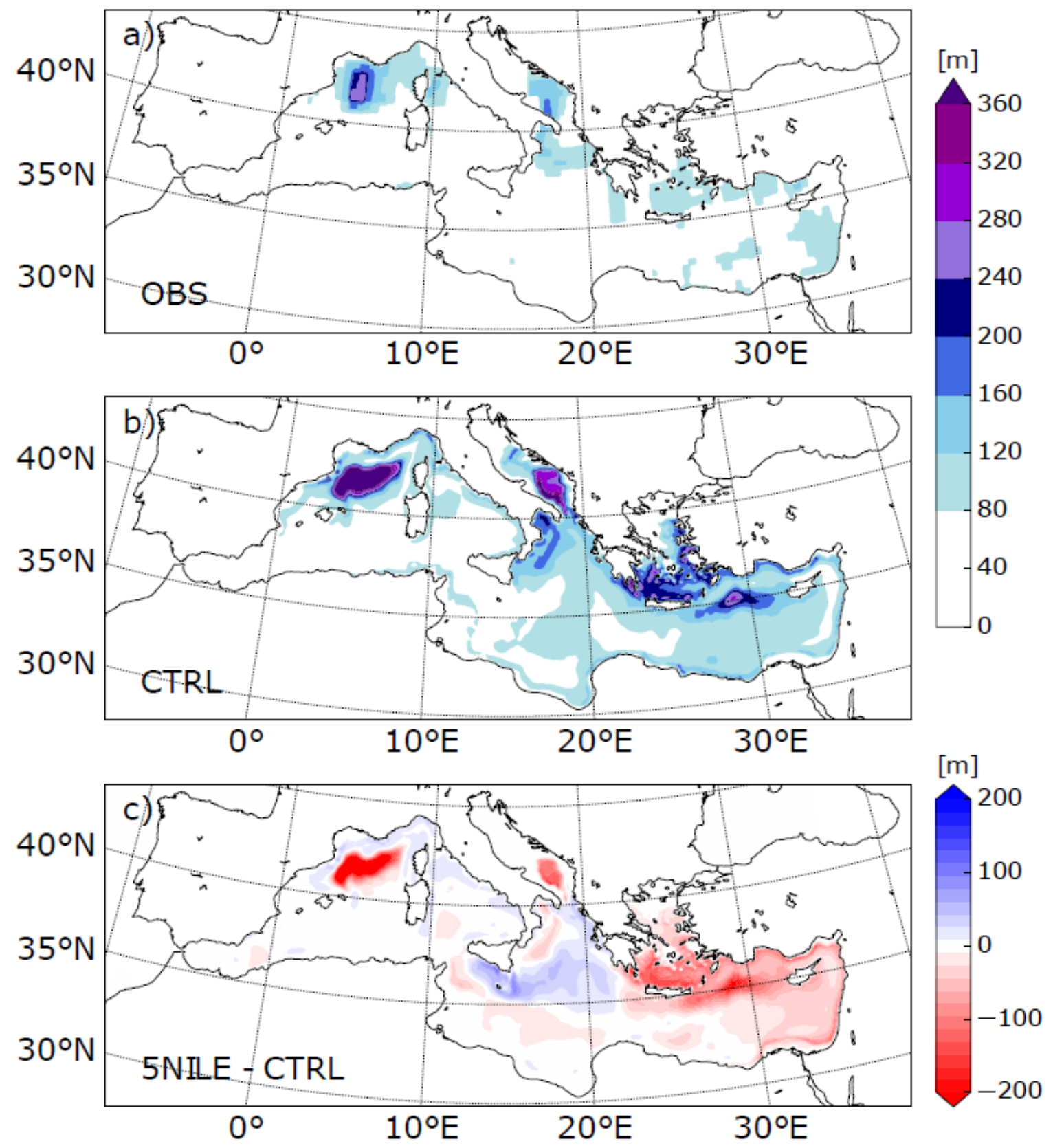

Figure 3. JFM mixed layer depth (MLD, in m), a) observation from Houpert et al. [2015], b) CTRL,

261 The zonal and meridional stream functions (ZOF and MOF) are useful diagnostics to analyze 262 the Mediterranean Thermohaline Circulation (MTC) for the present day (Somot et al. [2006]), 263 for future scenarios (Somot et al. [2006], Adloff et al. [2015]) and for paleoclimate studies 264 (Meijer and Tuenter [2007]], Meijer and Dijkstra [2009], Adloff et al. [2011]). We use the usual 265 definition of stream functions in meteorology and oceanography and a standard method to calculate them: 


$$
\begin{aligned}
& \operatorname{ZOF}(x, z)=\int_{h}^{z} \int_{y s}^{y s} u(x, y, z) d y d z \\
& \operatorname{MOF}(y, z)=\int_{h}^{z} \int_{x e}^{x w} v(x, y, z) d x d z
\end{aligned}
$$

, with ZOF and MOF being the zonal and meridional overturning stream functions, respectively. In Cartesian coordinates, $\mathrm{u}$ and $\mathrm{v}$ are the zonal and meridional currents, respectively, $\mathrm{h}$ is the depth of the bottom, and yn, $\mathrm{ys}, \mathrm{xw}$, Xe are respectively, the North, South, West, East coordinates. The ZOF for CTRL (averaged over the entire simulation) exhibits the main features of the MTC (Figure 4). The first cell is the surface and subsurface cell (in warm colors, clockwise) created by strong evaporation in the eastern basin (Bryden and Kinder [1991], Sanchez-Gomez et al. [2011]). The water deficit is compensated by flow through the Gibraltar Strait. The Atlantic water moves eastward along the African coast, gaining in salinity and density, so that by the time it enters the Levantine basin it sinks to intermediate depth $(200-600 \mathrm{~m})$ and returns westward into the Atlantic. The model reproduces this cyclonic surface circulation well (Millot and Taupier-Letage [2005]), with an inflow at Gibraltar of about 1Sv, consistent with observations (Bryden and Stommel [1984], Bormans and Garret [1989], Baringer and Price [1997], Garret [1996]). The second branch (in cold colors, counterclockwise) represents the intermediate and deep circulation. The combined effect of winter cold temperatures and strong winds leads to the formation of dense waters that sink to intermediate and deep levels Marshall and Schott [1999]. This process occurs preferentially at high surface salinity, i.e., in the Eastern Basin, to create the Levantine Intermediate Water (LIW, Figure 4a), mainly formed near Cyprus (Figure 3b). Flowing westward, LIW contributes to the formation of the Cretan Intermediate Water and Adriatic Deep Water. In CTRL, these waters initiate the convection patterns (Figures $4 \mathrm{c}$ and $4 \mathrm{~d}$ ). The LIW reaches the Western basin, becoming the EIW (Eastern Intermediate Water, since its properties are quite different from those of the initial LIW, Millot [2013]) and participates, in the Gulf of Lion, in the formation of the Western Mediterranean Deep Water (WMDW, Figure 4b) (Millot and Taupier-Letage [2005]). The circulation patterns simulated in CTRL are consistent with those in Somot et al. [2006] and Adloff et al. [2015], These latter using the same oceanic model (NEMOMED8), but a different atmospheric model. 

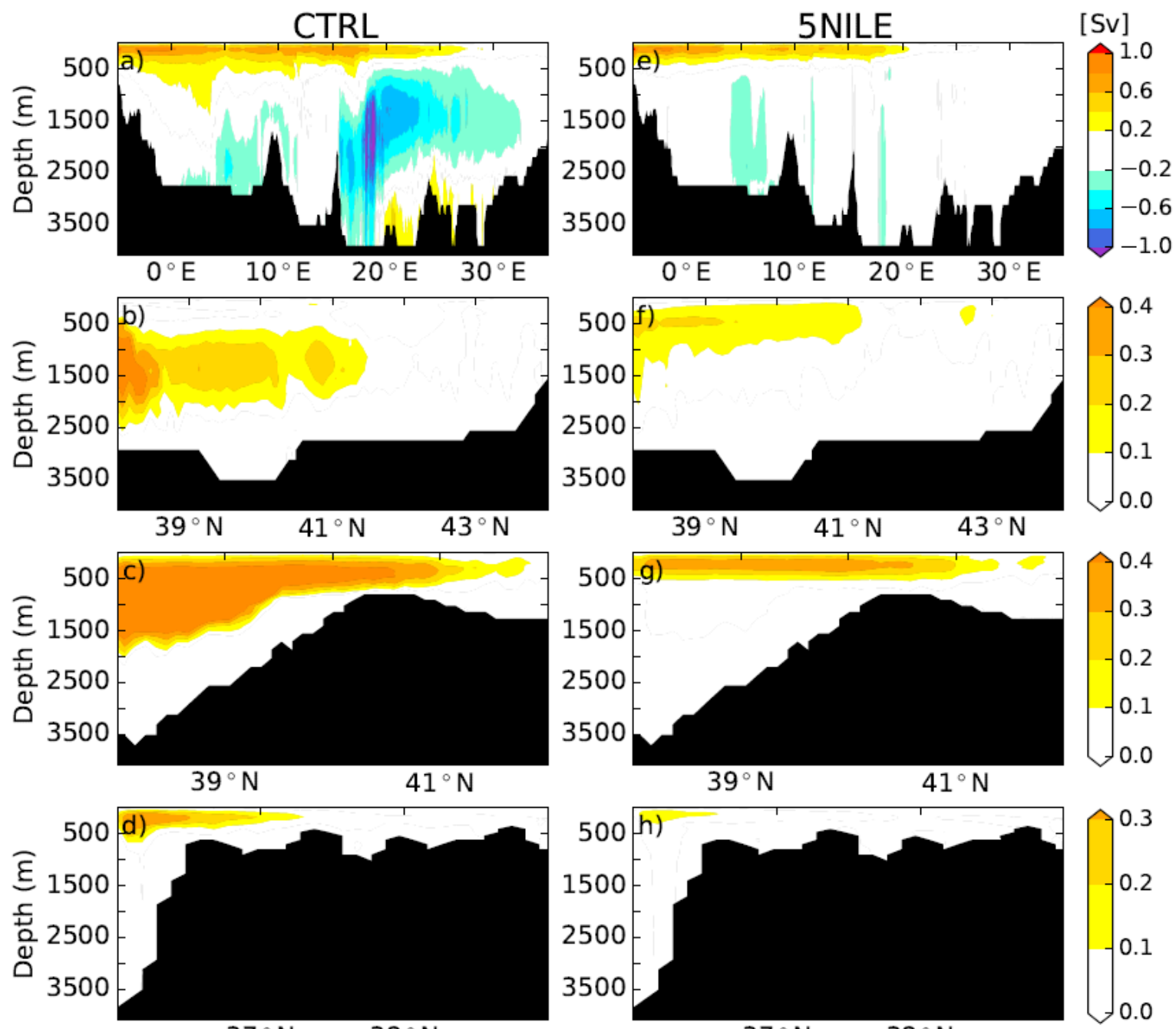

$37^{\circ} \mathrm{N}$

$38^{\circ} \mathrm{N}$

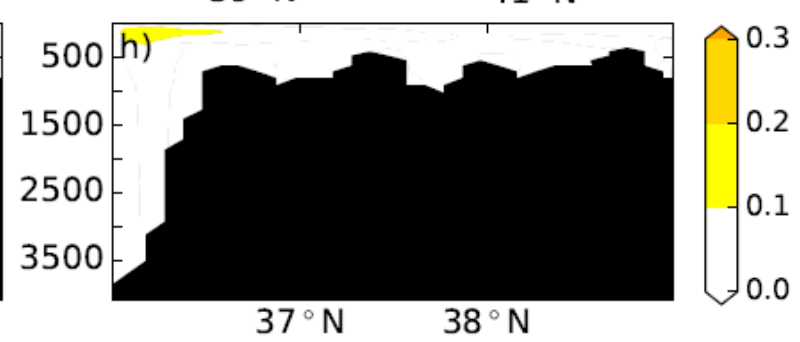

Figure 4. Overturning stream functions from CTRL (left column, a-d) and 5NILE (right column, e-h): a and e) Zonal Overturning stream Function (ZOF) in the section depth-longitude; $b$ and f) Meridional Overturning stream Function (MOF) in the section depth-latitude for the Gulf of Lions; c and g) MOF for the Adriatic Sea; $d$ and h) MOF for the Aegean Sea. All averaged over the entire simulation.

\subsubsection{Interannual variability of the convection}

301 Figure 5 shows the interannual variation of the MLD in the Gulf of Lions, the Adriatic Sea, the Aegean Sea and the Levantine basin, compared to the ZOF for the major eastern cell. In the CTRL experiment, MLD variability is pronounced in the Gulf of Lions, less intense in the Aegean, the Levantine and the Adriatic Seas. The ZOF variability is related to the formation of deep waters in the Levantine (for years 20-30 and around year 70), in some cases in the Adriatic Sea and Aegean Sea. A maximum of MLD is never reached simultaneously in the Adriatic and the Aegean Sea, showing that the model can reproduce an Eastern Mediterranean Transient Event -like mechanism, even with random forcing. 

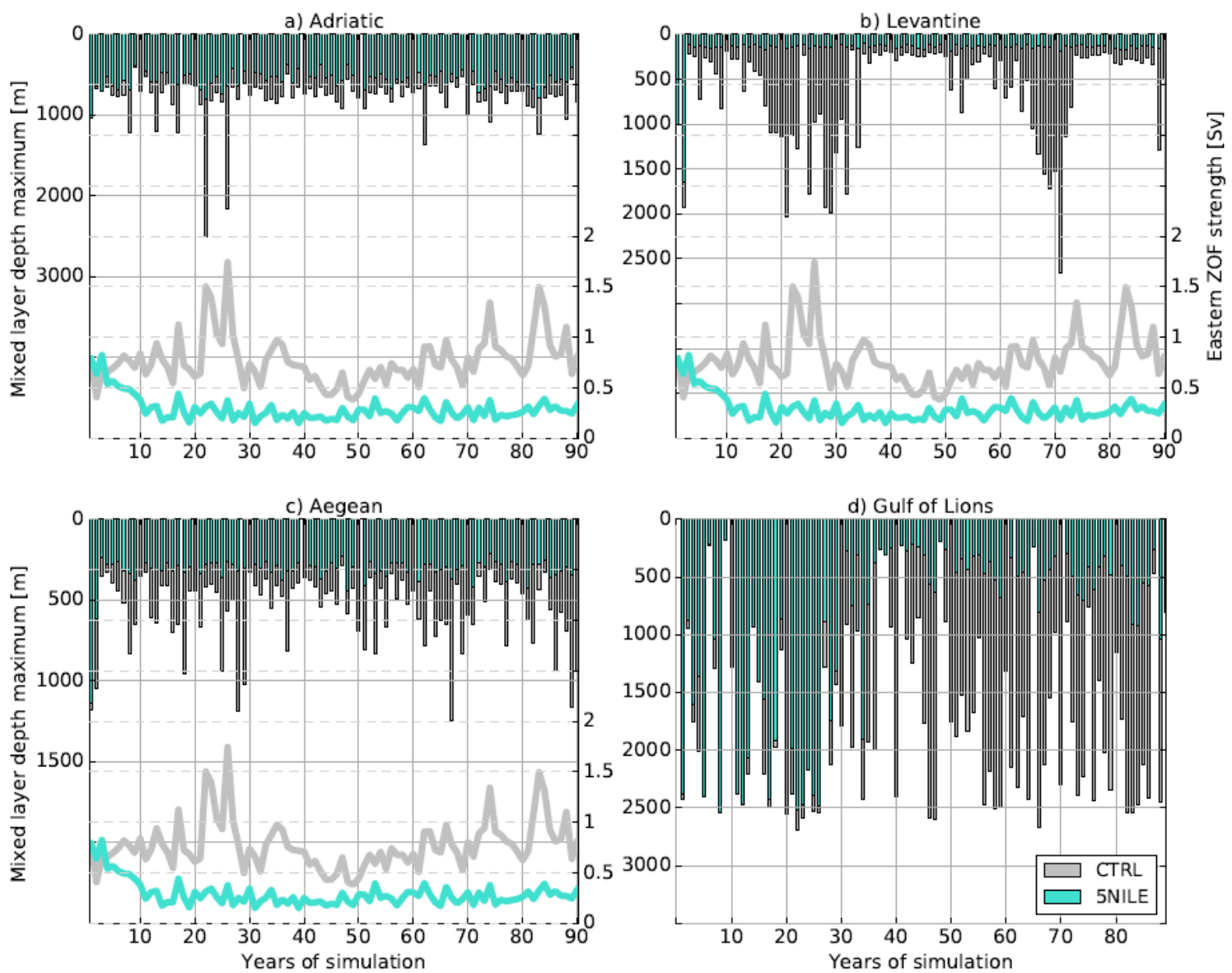

Figure 5. Interannual evolution of Mixed Layer Depth (bars, left vertical axis) for a) Adriatic Sea, b) Levantine basin, c) Aegean Sea, and d) Gulf of Lions. Superimposed curves in panels a, b and c show the strength of the zonal overturning stream function (ZOF) which characterizes the intensity of the Atlantic incoming water flow.

\subsection{Impact of enhanced Nile input on the MTC}

\subsubsection{A reduced circulation}

The most remarkable feature in the 5NILE experiment is the decrease in sea surface salinity (SSS) in the Levantine basin (Figure 6b), due to the enhanced freshwater input from the Nile. 5NILE shows a reduction of MLD over all convective areas of the Mediterranean Sea. MLD drops to a depth of 240m (from 400m in CTRL) in the Gulf of Lion, to 200-280m (from 350m) in the Adriatic Sea and to $80 \mathrm{~m}$ in the Cretan Sea (from 240m, Figure 3c). Circulation intensity is also reduced, as shown from the MOF and ZOF (Figure 4): the Nile perturbation affects both the eastern and western basins, with the upper cell shifting westward and becoming shallower while the intermediate and deep cells are strongly reduced. The reduction of MOF for the Adriatic, Aegean and Gulf of Lion is coherent with the overall reduction of MLD in 5NILE. In 
5NILE, the convection cell becomes shallower and more sluggish in the Adriatic, and completely disappears in the Aegean. The Gulf of Lion is also affected, with a reduced circulation cell shifted to shallower depth. The 5NILE experiment strongly reduces the MLD (and the ZOF) variability in the Gulf of Lion, where the two experiments CTRL and 5NILE behave similarly until year 35 .
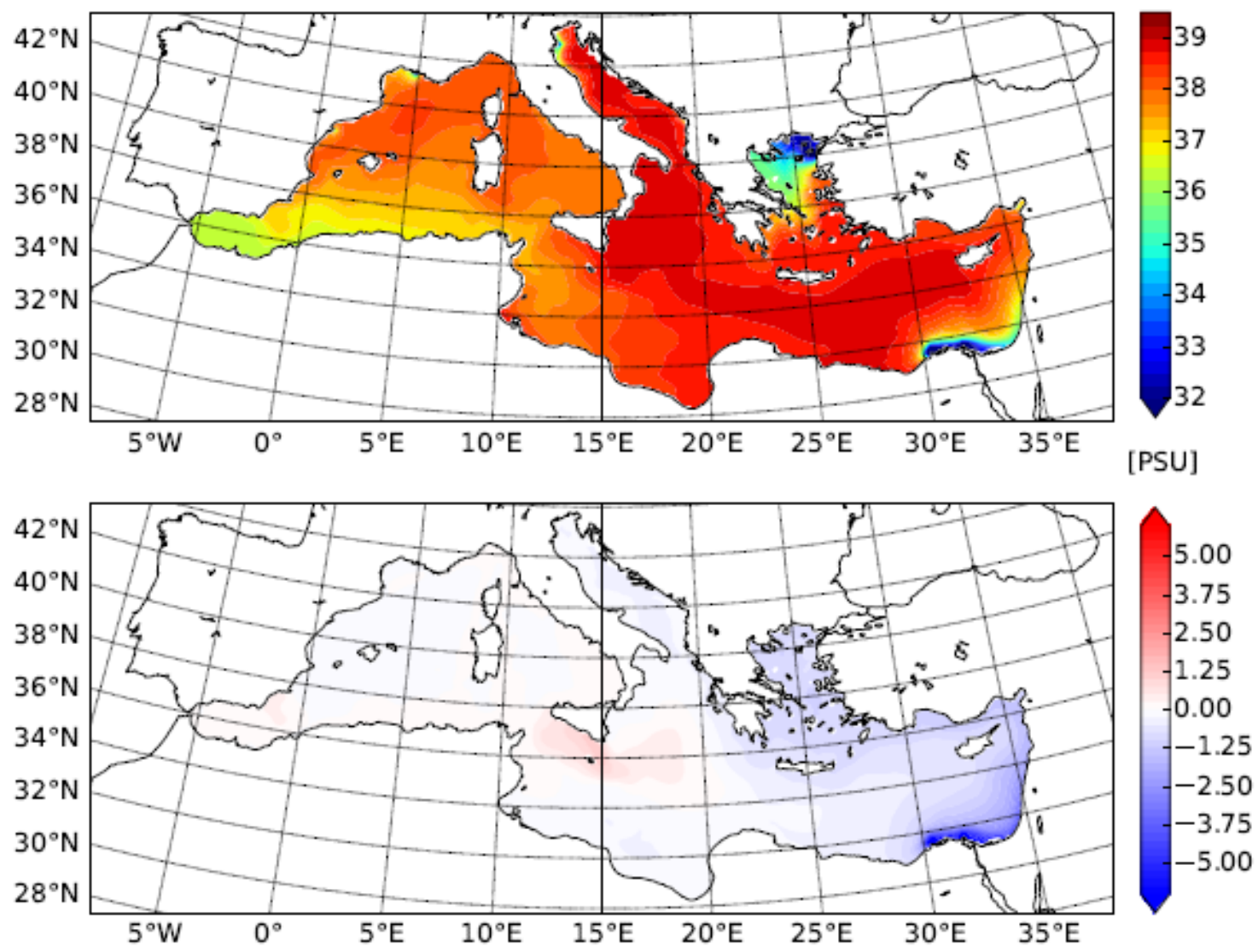

Figure 6. a) Sea Surface Salinity (SSS) for CTRL, b) SSS anomalies between 5NILE and CTRL (averaged over the entire simulation).

\subsection{Evaluation of the change in circulation with $\varepsilon \mathrm{Nd}$ tracer}

\subsubsection{Present-day Mediterranean $\varepsilon \mathrm{Nd}$ distribution: simulation vs. observations}

Figure 8a shows the simulated distribution of $\varepsilon N d$ and a comparison with observations for a vertical profile averaged over the whole Mediterranean. Figure $8 \mathrm{~b}$ shows vertical variations along a zonal transect. The model generally captures the observed east-west gradient in the surface layers from the Alboran Sea (-9.5) to the Levantine basin (-6). Water masses are more radiogenic at depth, and reach up to -3 in the Levantine and in the Libyan Sea at around 1500 $\mathrm{m}$. The comparison with observations reveals that the model overall generates water that is too 
radiogenic, similar to Ayache et al. [2016]. Despite the excessive radiogenic behavior, the model reproduces a vertical pattern similar to that in the observations, especially the more radiogenic signature at intermediate depths $(500-800 \mathrm{~m})$, associated with LIW. We conclude that the incorporation of the neodymium tracer in the model introduces an interesting tool to investigate circulation anomalies in the Mediterranean (Ayache et al. [2016]).
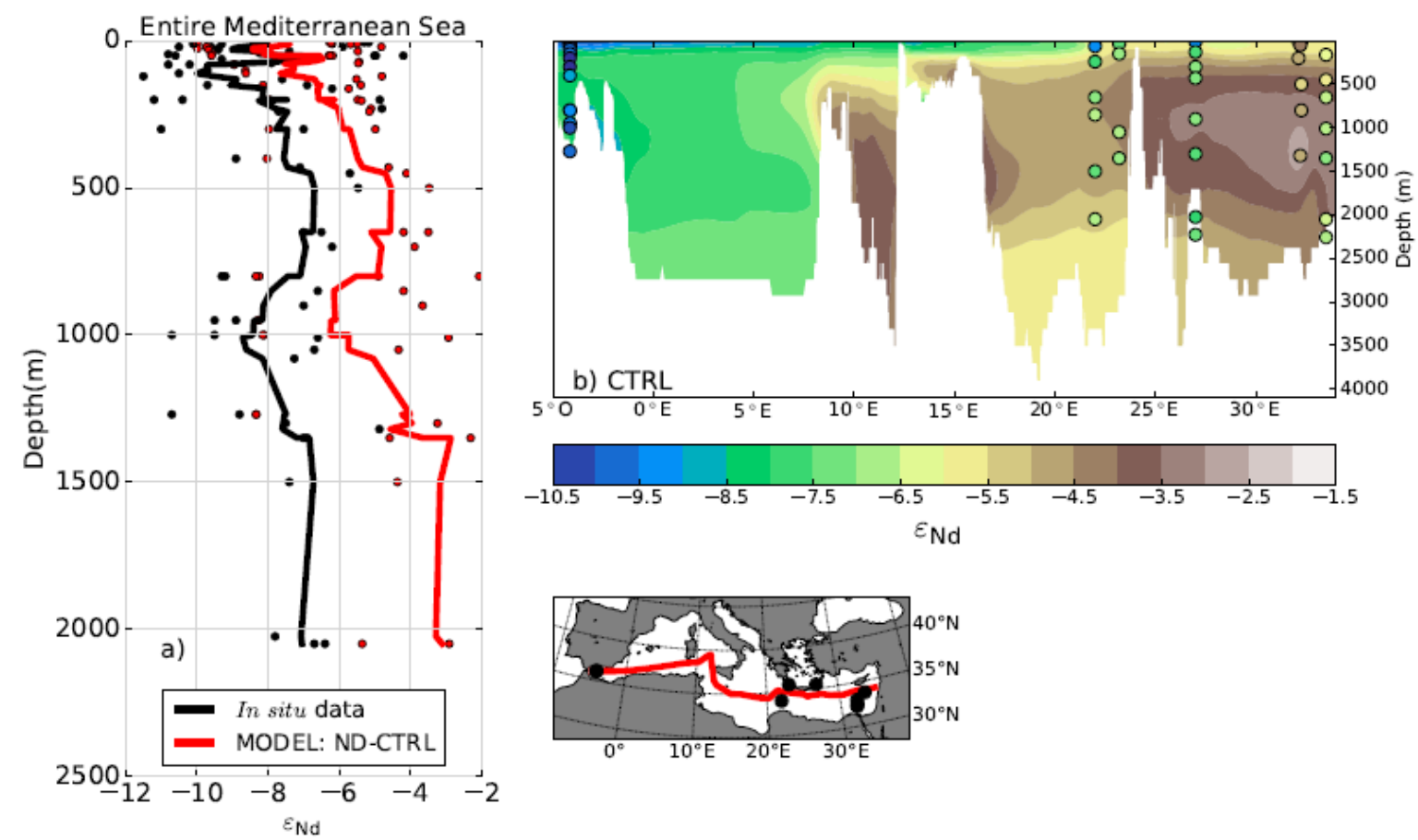

Figure 7. a) Entire Mediterranean $\varepsilon N d$ vertical distribution for CTRL and in situ data (Tachikawa et al. [2004], Vance et al. [2004], b), \&Nd vertical transect for CTRL, dots represent in situ data (Tachikawa et al. [2004], Vance et al. [2004].

\subsubsection{Impact of a weaker circulation on the $\varepsilon \mathrm{Nd}$ distribution}

Variations in $\varepsilon N d$ distribution between CTRL and 5NILE at different levels of the Mediterranean, i.e., at the surface, at 500m and at 1500m (Figure 8), as well as in a transect from west to east (Figure 9). The hosing experiment generally reproduces less radiogenic water masses in the western basin, as a result of reduced exchange with the eastern basin. In the eastern basin, however, we observe less radiogenic waters at the surface in the Levantine basin, but more radiogenic ones in the Ionian basin. These variations in $\varepsilon \mathrm{Nd}$ at the surface are consistent with changes in surface currents. The surplus freshwater input from the Nile has two major effects: first, the current in the Levantine basin is intensified, especially south of Crete and along the eastern Libyan coast, and second, the inflow from the west is shifted southward 
into the Gulf of Gabès instead of entering the Ionian Sea (Figure 8a)?. Consequently, the current

364 structure of the eastern basin surface in 5NILE shows conditions favorable to the propagation

365 of low-radiogenic western water into the Levantine basin and its mixing with the freshwater 366 from the Nile. The increased $\varepsilon N d$ signal simulated in the Ionian Sea is caused by enhanced surface currents bringing more radiogenic waters from the north Levantine basin. At

368 intermediate depth $(500 \mathrm{~m})$, near the LIW, the Mediterranean becomes less radiogenic overall, 369 with the exception of the Cretan Sea (Figure 8b). This signal, also clearly detectable along the 370 transect (Figure 9), documents the less vigorous circulation and reduced LIW. Both reduce the 371 exchange with high-radiogenic material from the east, and affect the overall connection 372 between the eastern and western basins. At greater depth (1500m; Figure 8c), anomalies are 373 more radiogenic in the eastern basin and the Tyrrhenian Sea, and less negative in the west in 374 the Alboran Sea and in the Ligurian sub-basin. This is the consequence of the sluggish 375 circulation simulated in 5NILE, which reproduces stagnation in deep waters that generates a $376 \varepsilon \mathrm{Nd}$ signature closer to the value of the surrounding margins. 

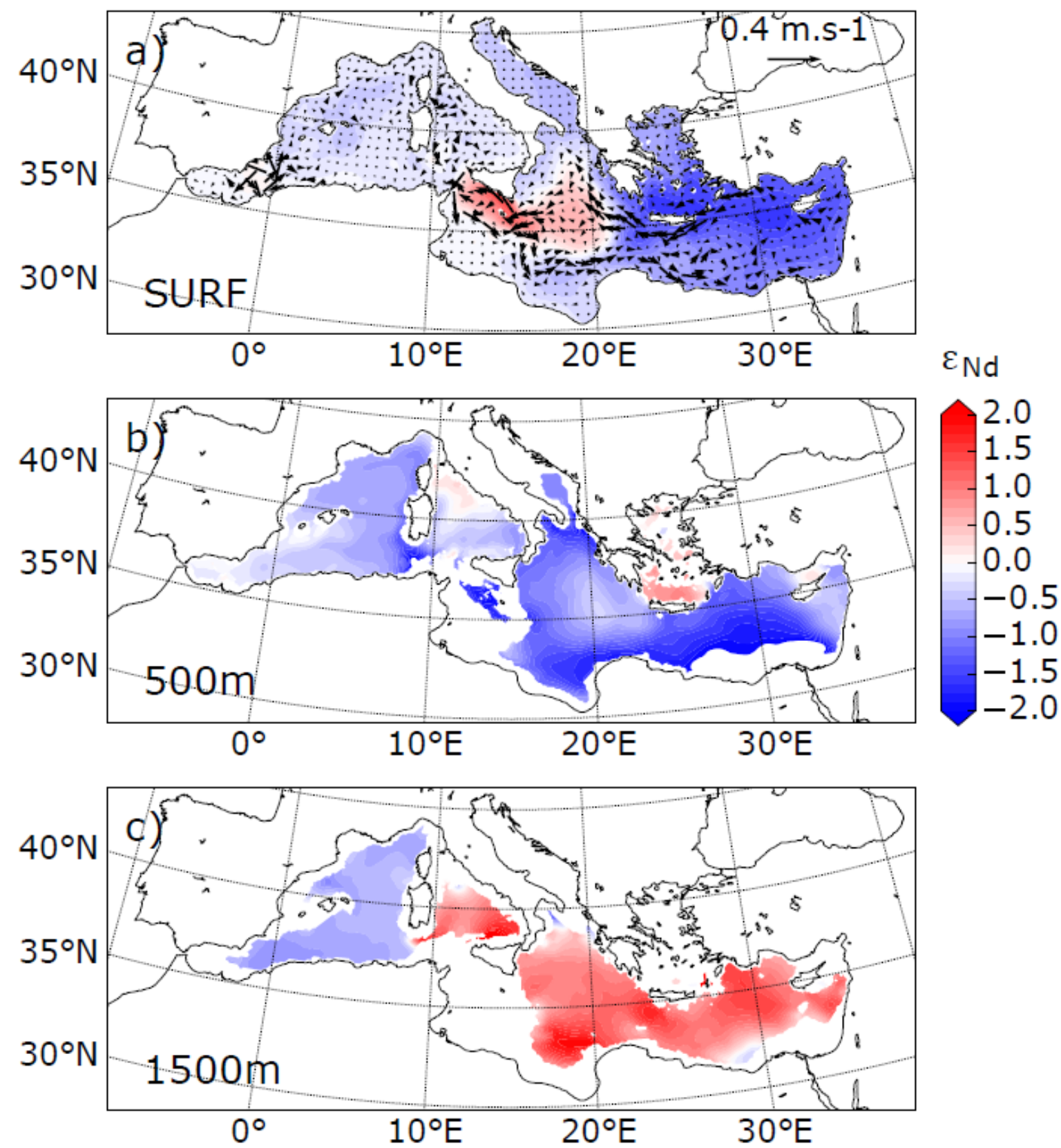

Figure 8. $\varepsilon N d$ anomalies between 5NILE and CTRL. a) Sea surface regarding sea surface velocities anomalies (5NILE vs CTRL), b) $500 \mathrm{~m}$, c) $1500 \mathrm{~m}$.

\subsubsection{Comparison with $\varepsilon \mathrm{Nd}$ reconstructions for the S1 period}

382 Few existing $\varepsilon N d$ reconstructions provide data for the last sapropel period in the Alboran Sea

383 (Jiménez-Espejo et al. [2015]), Sardinia Channel (Dubois-Dauphin et al. [2016]), eastern Levantine and the Sicily-Tunisian Strait (Cornuault et al. [2018]). Figure 9 summarizes the $\varepsilon N d$ anomalies in 5NILE along a transect from west to east in the Mediterranean, with available observations superimposed. At the Sardinia Channel, observations of Dubois-Dauphin et al. [2016] display an anomaly of about $-0.73 \varepsilon N d$ between sapropel S1 and the modern (ventilated) 
period. It is thought that this anomaly is the result of a weaker circulation and reduced LIW/EIW during the Early and Late Holocene. Before and after the S1 Sardinian Cold-Water Corals (CWC) were under the influence of the Cretan intermediate water which was highly radiogenic. During S1, Sardinian CWC were not in contact with the LIW/EIW and, instead, were potentially in contact with the less radiogenic Western Intermediate Water (WIW) (DuboisDauphin et al. [2016]). The model can simulate less radiogenic values in the water of the Sardinia Channel with a reasonably accurate amplitude $(-0.78 \varepsilon N d$ in the model, $-0.73 \varepsilon N d$ in the observations). The core in the Levantine Basin (1781m, Cornuault et al. [2018]) depicts the changes of deep circulation in the Eastern basin (and does not reflect the LIW). It shows more radiogenic waters during sapropel events than during modern times $(+2.7 \varepsilon \mathrm{Nd}$, Figure 10) (Cornuault et al. [2018]). This can be attributed to the combined effect of a reduced circulation that transports less low-radiogenic water from the western basin, and an enhanced flux of radiogenic materials from the Nile river. It is more difficult to compare the core in the Levantine basin with our simulation because of the influence of the riverine $\varepsilon \mathrm{Nd}$. The model reproduces a signal similar to observations, but with a weaker amplitude (+0.9 $\varepsilon N d$ from 5NILE - CTRL, Figure 9). This result suggests that at $1781 \mathrm{~m}$, the depth of the core, observations are greatly affected by the change in deep circulation. It is also suggested that other mechanisms such as the input of radiogenic particles have to be taken into account in order to simulate the correct amplitude of the observed signal. The situation is similar at the Sicily-Tunisian Strait (771m), where observations also depict more radiogenic waters during the sapropel deposition than the modern seawater signature $(+2.5 \varepsilon \mathrm{Nd})$. The model reproduces the positive signal, but at an order of magnitude lower $(+0.2 \varepsilon N d$, Figure 9$)$. The simulation suggests that this observation is located in a region where strong gradients in the $\varepsilon \mathrm{Nd}$ anomaly are produced, so that this signal is difficult to analyse. The records at shallower depth, more characteristic of LIW, may also be significantly influenced by the signal generated by the enhanced radiogenic flux from Nile river input, or from dust deposition, rather than by the the change in circulation. In the core retrieved in the Alboran Sea, a $\varepsilon N d$ signature of -9.75 was sampled at the end of the S1 (6970 years BP) (Jiménez-Espejo et al. [2015]). This gives a difference of - $0.45 \varepsilon N d$ with the modern Alboran seawater signature, -9.3 (Tachikawa et al., 2004). The imprint from the hosing experiment reproduces a close signal $(-0.5 \varepsilon \mathrm{Nd})$, even if the $\varepsilon \mathrm{Nd}$ boundary condition imposed for both experiments in the Atlantic buffer-zone is the same $(-11 \varepsilon \mathrm{Nd})$, and it is likely that the Atlantic signature was different during the Early Holocene. 

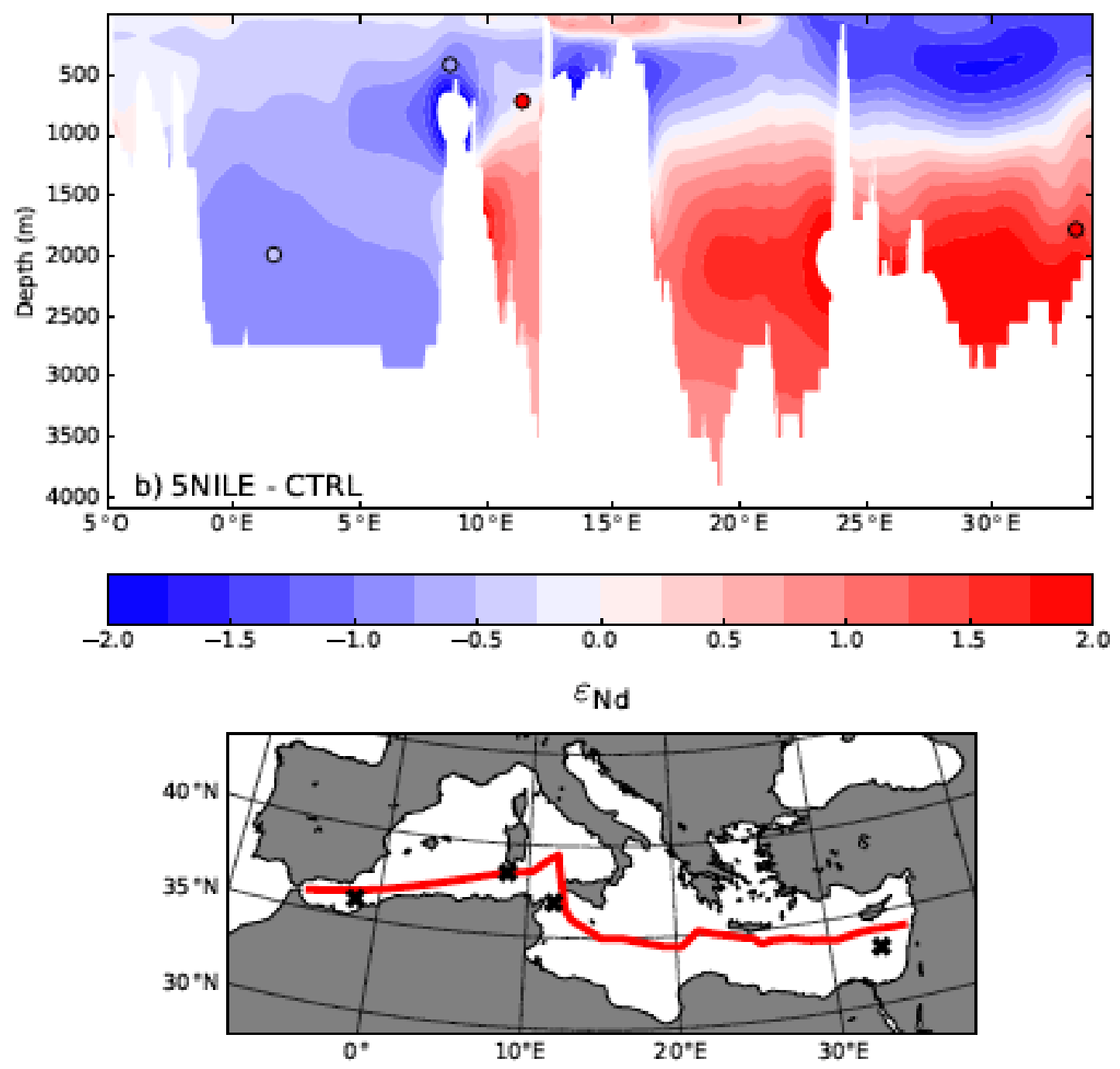

Figure 9. $\varepsilon \mathrm{Nd}$ anomalies (5NILE vs CTRL) in vertical transect, dots represents the $\varepsilon \mathrm{Nd}$ signal recorded in Alboran Sea (Jiménez-Espejo et al. [2015]), Sardinia Chanel, Dubois-Dauphin et al. [2016], Sicily Strait and Levantine basin (Cornuault et al. [2018] for both). The data are shown in comparison to modern $\varepsilon \mathrm{Nd}$ values.

\section{Conclusion and perspective}

\subsection{Overview of the results and limits of the modeling}

\subsubsection{Changes in Ocean Dynamics}

429 Our results show that a shutdown of convection in the Eastern Mediterranean basin may be 430 triggered by the direct action of the precession cycle on the monsoon precipitation and on the 431 consequent freshwater input from the Nile. The enhanced Nile freshwater input, which is 432 estimated as 5 times its pre-industrial amount in the Early Holocene, strongly affects the 
dynamics of the whole Mediterranean Sea, and especially the convection in different key areas, with shoaling of the MLD over convection spots and reduction of deep and intermediate water circulation. The Nile perturbation also affects the Western Mediterranean Sea by reducing convection in the Gulf of Lion. The reduced salinity of the surface waters in the Western basin (Figure 6) impacts convection as well as the LIW/EIW transport from the Eastern basin.

\subsubsection{Oceanic circulation changes revealed with epsilon Neodymium}

We further explored the evolution of circulation changes through the simulation of $\varepsilon \mathrm{Nd}$ in our model. Equilibrium of major oceanic circulations was achieved after 90 years. Some biases of epsilon Nd were identified in our control simulation, with two possible sources. First, in the current version of our model, only the exchange of $\mathrm{Nd}$ with the continental margin was considered, with dust deposition and neodymium input from rivers neglected. This simplified approach generates too-high radiogenic $\varepsilon N d$ values (Ayache et al. [2016]). Preliminary studies indicate that including dust deposition can improve the simulation of $\varepsilon \mathrm{Nd}$ (Ayache et al. [2016]). Second, the excessively strong convection in the Eastern basin reproduced in the model potentially increases the exchange with the Eastern margin and may lead to radiogenic values that are too high in this area at depth. Despite these biases, the simulated $\varepsilon N d$ is very useful to assess oceanic circulation changes during the sapropel deposition. As in Ayache et al. [2016] dealing with the EMT, our experiment for S1 revealed consistent changes in the $\varepsilon \mathrm{Nd}$ distribution. Our results show that the change in circulation generates $\varepsilon \mathrm{Nd}$ anomalies that explain a large part of the signal observed in paleo-archives. The lower radiogenic $\varepsilon N d$ signal recorded in the Sardinia Channel during the sapropel deposition is associated with a reduction of LIW transporting normally highly radiogenic water masses from the Eastern basin. Our study also suggests that the signal recorded in the Levantine basin is largely affected by the reduction in circulation.

\subsection{Perspectives for future studies}

This paper is our first attempt to study the effect of the Nile freshwater perturbation on the Mediterranean circulation using a high-resolution regional ocean-atmosphere fully coupled model. We would like to examine the hypothesis that the increase in the Nile river discharge during the last African humid period was the trigger of the last sapropel deposition in the Early Holocene. The present experimental design and model setup do not allow an anoxic environment to be reached or the stability of the perturbation over the entire S1 time scale to be studied. Instead, we focused on the change in oceanic dynamics using the $\varepsilon N d$ simulation (faster than the biogeochemistry). Nd is an interesting tracer, suitable to study past oceanic circulation. 
Our next step is to implement a complete Nd scheme in our model, by including other sources of $\mathrm{Nd}$, such as dust deposition and river discharges. A full understanding of the S1 event needs a good representation of the whole hydrological cycle of Early Holocene climate, because of the contrasting seasonality of this period compared to nowadays. It is necessary to include the evaporation and precipitation fluxes over the Mediterranean Sea and the river runoff changes, not only from the Nile but also from the North West African Margin and the East European Region, caused by changes in continental precipitation. Finally, from a practical point of view, our full coupling between the atmosphere and ocean is very time consuming and does not allow us to perform very long simulations with limited resources. We are thus developing a sequential way to perform simulations similar to that used in Adloff [2011] and Adloff et al. [2011], while maintaining a high resolution in the regional atmosphere (LMDz-regional, $30 \mathrm{~km}$ horizontal resolution). We expect to find a balance between a good simulation of the specificity of the Mediterranean region and the need to run long-duration oceanic simulations.

\section{Acknowledgments}

We thank Marine Cornuault and Quentin Dubois-Dauphin for sharing their data in this study framework. We also thank the two anonymous referee for their constructive comments. We thank Mary Minnock for her professional English revision. This work was granted access to the HPC resources of TGCC under the allocation 2017-A0010102212 and 2018-A0030102212 made by GENCI.

\section{References}

Adloff, F. (2011), Early Holocene Eastern Mediterranean ocean climate and the stability of its overturning circulation, Ph.D. thesis.

Adloff, F., U. Mikolajewicz, M. Kucera, R. Grimm, E. Maier-Reimer, G. Schmiedl, and K. C. Emeis (2011), Upper ocean climate of the Eastern Mediterranean Sea during the Holocene Insolation Maximum - A model study, Climate of the Past, 7(4), 1103-1122, doi:10.5194/cp-7-1103-2011.

Adloff, F., S. Somot, F. Sevault, G. Jordà, R. Aznar, M. Déqué, M. Herrmann, M. Marcos, C. Dubois, E. Padorno, E. Alvarez-Fanjul, and D. Gomis (2015), Mediterranean Sea response to climate change in an ensemble of twenty first century scenarios, Climate Dynamics, 45(9-10), 2775-2802, doi:10.1007/s00382-015-2507-3. 
Paleoceanography and Paleoclimatology. 34(2), 237-251, https://doi.org/10.1029/2019PA003566

Arsouze, T. (2007), Modélisation du cycle océanique du néodyme, Ph.D. thesis.

Arsouze, T., J. C. Dutay, F. Lacan, and C. Jeandel (2007), Modeling the neodymium isotopic composition with a global ocean circulation model, Chemical Geology, 239(1-2), 165-177, doi:10.1016/j.chemgeo.2006.12.006.

Arsouze, T., J.-C. Dutay, M. Kageyama, F. Lacan, R. Alkama, O. Marti, and C. Jeandel (2008), A modeling sensitivity study of the influence of the Atlantic meridional overturning circulation on neodymium isotopic composition at the Last Glacial Maximum, Climate of the Past, 4(3), 191-203, doi:10.5194/cp-4-191-2008.

Arsouze, T., J.-C. Dutay, F. Lacan, and C. Jeandel (2009), Reconstructing the Nd oceanic cycle using a coupled dynamical - biogeochemical model, Biogeosciences Discussions, 6(3), 5549-5588, doi:10.5194/bgd-6-5549-2009.

Ayache, M., J.-C. Dutay, T. Arsouze, S. Révillon, J. Beuvier, and C. Jeandel (2016), High resolution neodymium characterization along the Mediterranean margins and modeling of_Nd distribution in the Mediterranean basins, Biogeosciences, (April), 1-31, doi: 10.5194/bg-2016-109.

Baringer, M. O., and J. F. Price (1997), Mixing and Spreading of the Mediterranean Outflow, Journal of Physical Oceanography, 27(8), 1654-1677, doi:10.1175/15200485(1997)027<1654:MASOTM>2.0.CO;2.

Béranger, K., Y. Drillet, M.-N. Houssais, P. Testor, R. Bourdallé-Badie, B. Alhammoud, A. Bozec, L. Mortier, P. Bouruet-Aubertot, and M. Crépon (2010), Impact of the spatial distribution of the atmospheric forcing on water mass formation in the Mediterranean Sea, Journal of Geophysical Research, 115(C12), C12,041, doi:10.1029/2009JC005648.

Bethoux, J.-P. (1993), Mediterranean sapropel formation, dynamic and climatic viewpoints, Oceanologica Acta, 16(2), 127-133.

Beuvier, J., F. Sevault, M. Herrmann, H. Kontoyiannis, W. Ludwig, M. Rixen, E. Stanev, K. Branger, and S. Somot (2010), Modeling the Mediterranean Sea interannual variability during 1961-2000: Focus on the Eastern Mediterranean Transient, Journal of 
Paleoceanography and Paleoclimatology. 34(2), 237-251, https://doi.org/10.1029/2019PA003566

Geophysical Research: Oceans, 115(8), 1-27, doi:10.1029/2009JC005950.

Bianchi, D., M. Zavatarelli, N. Pinardi, R. Capozzi, L. Capotondi, C. Corselli, and S. Masina (2006), Simulations of ecosystem response during the sapropel S1 deposition event, Palaeogeography, Palaeoclimatology, Palaeoecology, 235(1-3), 265-287, doi: 10.1016/j.rvsc.2005.11.002.

Bormans, M., and C. Garret (1989), The effect of Rotation on the Surface Inflow through the Strait of Gibraltar, Journal of Physical Oceanography, 19, 1535 - 1542, doi: 10.1175/1520-0485(1989)019<1535:TEOROT>2.0.CO;2.

Braconnot, P., B. Otto-Bliesner, S. Harrison, S. Joussaume, J. Peterchmitt, A. Abe-Ouchi, M. Crucifix, E. Driesschaert, T. Fichefet, C. Hewitt, M. Kageyama, A. Kitoh, A. Laîné, M. Loutre, O. Marti, U. Merkel, G. Ramstein, P. Valdes, S. Weber, Y. Yu, and Y. Zhao (2007), Results of PMIP2 coupled simulations of the Mid-Holocene and Last Glacial Maximum - Part 1: experiments and large-scale features, Climate of the Past, 3(2), 261277, doi:10.5194/cp-3-261-2007.

Bryden, H. L., and T. H. Kinder (1991), Steady two-layer exchange through the Strait of Gibraltar, Deep Sea Research Part A. Oceanographic Research Papers, 38, Supple(0), S445-S463, doi:http://dx.doi.org/10.1016/S0198-0149(12)80020-3.

Bryden, H. L., and H. M. Stommel (1984), Limiting processes that determine basic features of the circulation in the Mediterranean Sea, Oceanologica Acta, 7(3), 289-296.

Calvert, S. E., B. Nielsen, and M. R. Fontugne (1992), Evidence from nitrogen isotope ratios for enhanced productivity during formation of eastern Mediterranean sapropels, Nature, 359(6392), 223-225, doi:10.1038/359223a0.

Casford, J. S. L., E. J. Rohling, R. H. Abu-Zied, C. Fontanier, F. J. Jorissen, M. J. Leng, G. Schmiedl, and J. Thomson (2003), A dynamic concept for eastern Mediterranean circulation and oxygenation during sapropel formation, Palaeogeography, Palaeoclimatology, 
Paleoceanography and Paleoclimatology. 34(2), 237-251, https://doi.org/10.1029/2019PA003566 Palaeoecology, 190, 103-119, doi:10.1016/S0031-0182(02)00601-6.

Cornuault, M., K. Tachikawa, L. Vidal, A. Guihou, G. Siani, P. Deschamps, F. Bassinot, and M. Revel (2018), Circulation changes in the eastern Mediterranean Sea over the past 23,000 years inferred from authigenic $\mathrm{Nd}$ isotopic ratios, Paleoceanography and Paleoclimatology, pp. 264-280, doi:10.1002/2017PA003227.

Cramp, A., and G. O'Sullivan (1999), Neogene sapropels in the Mediterranean: A review, Marine Geology, 153(1-4), 11-28, doi:10.1016/S0025-3227(98)00092-9.

De Lange, G. J., J. Thomson, A. Reitz, C. P. Slomp, M. Speranza Principato, E. Erba, and C. Corselli (2008), Synchronous basin-wide formation and redox-controlled preservation of a Mediterranean sapropel, Nature Geoscience, 1(9), 606-610, doi:10.1038/ngeo283.

Demenocal, P., J. Ortiz, T. Guilderson, J. Adkins, M. Sarnthein, L. Baker, and M. Yarusinsky (2000), Abrupt onset and termination of the African Humid Period: Rapid climate responses to gradual insolation forcing, Quaternary Science Reviews, 19(1-5), 347-361, doi:10.1016/S0277-3791(99)00081-5.

Dubois-Dauphin, Q., P. Montagna, G. Siani, E. Douville, C. Wienberg, D. Hebbeln, Z. Liu, N. Kallel, A. Dapoigny, M. Revel, E. Pons-Branchu, and C. Colin (2016), Hydrological variations of the intermediate water masses of the western Mediterranean Sea during the past $20 \mathrm{ka}$ inferred from neodymium isotopic composition in foraminifera and cold-water corals, Climate of the Past Discussions, (June), 1-36, doi:10.5194/cp-2016-64.

Emeis, K.-C., H. Schulz, U. Struck, M. Rossignol-Strick, H. Erlenkeuser, M. W. Howell, D. Kroon, a. Mackensen, S. Ishizuka, T. Oba, T. Sakamoto, and I. Koizumi (2003), Eastern Mediterranean surface water temperatures and _ $18 \mathrm{O}$ composition during deposition of sapropels in the late Quaternary, Paleoceanography, 18(1), n/a-n/a, doi: 10.1029/2000PA000617.

Frank, M. (2002), Radiogenic isotopes: Tracers of past ocean circulation and erosional input, Reviews of Geophysics, 40(1), doi:10.1029/2000RG000094. 
Paleoceanography and Paleoclimatology. 34(2), 237-251, https://doi.org/10.1029/2019PA003566

577 Freydier, R., A. Michard, G. De Lange, and J. Thomson (2001), Nd isotopic compositions of Eastern Mediterranean sediments: Tracers of the Nile influence during sapropel S1 formation?, Marine Geology, 177(1-2), 45-62, doi:10.1016/S0025-3227(01)00123-2.

Garret, C. (1996), The role of the Strait of Gibraltar in the evolution of Mediterranean water, properties and circulation, in Bull. Inst. océanogr. Monaco, vol. nº spécial, pp. $1-40$.

Grant, K., R. Grimm, U. Mikolajewicz, G. Marino, M. Ziegler, and E. Rohling (2016), The timing of Mediterranean sapropel deposition relative to insolation, sea-level and African monsoon changes, Quaternary Science Reviews, 140, 125-141, doi: 10.1016/j.quascirev.2016.03.026.

Grimm, R. (2012), Simulating the early Holocene eastern Mediterranean sapropel formation using an ocean biogeochemical model, Ph.D. thesis.

Grimm, R., E. Maier-Reimer, U. Mikolajewicz, G. Schmiedl, K. Müller-Navarra, F. Adloff, K. M. Grant, M. Ziegler, L. J. Lourens, and K.-C. Emeis (2015), Late glacial initiation of Holocene eastern Mediterranean sapropel formation, Nature Communications, 6(7099), 12pp, doi:10.1038/ncomms8099.

Hamon, N., P. Sepulchre, V. Lefebvre, and G. Ramstein (2013), The role of eastern Tethys seaway closure in the Middle Miocene Climatic Transition (ca. 14 Ma), Climate of the Past, 9(6), 2687-2702, doi:10.5194/cp-9-2687-2013.

Hennekam, R., T. Jilbert, B. Schnetger, and G. J. De Lange (2014), Solar forcing of Nile discharge and sapropel S1 formation in the early to middle Holocene eastern Mediterranean,Paleoceanography, 29(5), 343-356, doi:10.1002/2013PA002553.

Henry, F., C. Jeandel, B. Dupré, and J. F. Minster (1994), Particulate and dissolved Nd in the western Mediterranean Sea: Sources, fate and budget, Marine Chemistry, 45(4), 283-305, doi:10.1016/0304-4203(94)90075-2.

Houpert, L., P. Testor, X. D. de Madron, S. Somot, F. D’Ortenzio, C. Estournel, and 
H. Lavigne (2015), Seasonal cycle of the mixed layer, the seasonal thermocline and the upper-ocean heat storage rate in the Mediterranean Sea derived from observations, Progress in Oceanography, 132, 333-352, doi:10.1016/j.pocean.2014.11.004.

Hourdin, F., I. Musat, S. Bony, P. Braconnot, F. Codron, J. L. Dufresne, L. Fairhead, M. A. Filiberti, P. Friedlingstein, J. Y. Grandpeix, G. Krinner, P. LeVan, Z. X. Li, and F. Lott (2006), The LMDZ4 general circulation model: Climate performance and sensitivityto parametrized physics with emphasis on tropical convection, Climate Dynamics,27(7-8), 787-813, doi:10.1007/s00382-006-0158-0.

Jacobsen, S. B., and G. J. Wasserburg (1980), Sm-Nd isotopic evolution of chondrites, Earth and Planetary Science Letters, 50(1), 139-155, doi:10.1016/0012821X(80)90125-9.

Jiménez-Espejo, F. J., M. Pardos-Gené, F. Martínez-Ruiz, A. García-Alix, T. van de Flierdt, T. Toyofuku, A. Bahr, and K. Kreissig (2015), Geochemical evidence for intermediate

water circulation in the westernmost Mediterranean over the last 20kyrBP and its impact on the Mediterranean Outflow, Global and Planetary Change, 135, 38-46, doi:10.1016/j.gloplacha.2015.10.001.

Kallel, N., M. Paterne, J. C. Duplessy, C. Vergnaud-Grazzini, C. Pujol, L. Labeyrie, M. Arnold, M. Fontugne, and C. Pierre (1997), Enhanced rainfall in the Mediterranean region during the last Sapropel Event, Oceanologica Acta, 20, 697-712, doi: http://dx.doi.org/10.1016/S0031-0182(97)00021-7.

Kallel, N., J. C. Duplessy, L. Labeyrie, M. Fontugne, M. Paterne, and M. Montacer (2000), Mediterranean pluvial periods and sapropel formation over the last 200000 years, Palaeogeography, Palaeoclimatology, Palaeoecology, 157(1-2), 45-58, doi: 10.1016/S0031-0182(99)00149-2.

Krom, M. D., A. Michard, R. A. Cliff, and K. Strohle (1999), Sources of sediment to the 
Paleoceanography and Paleoclimatology. 34(2), 237-251, https://doi.org/10.1029/2019PA003566

629

630

631

632

633

634

635

636

637

638

639

640

641

642

643

644

645

646

647

648

649

650

651

652

653

654

655

Ionian Sea and western Levantine basin of the Eastern Mediterranean during S-1 sapropel times, Marine Geology, 160(1-2), 45-61, doi:10.1016/S0025-3227(99)000158.

Kuhnt, T., G. Schmiedl, W. Ehrmann, Y. Hamann, and C. Hemleben (2007), Deepsea ecosystem variability of the Aegean Sea during the past $22 \mathrm{kyr}$ as revealed by Benthic Foraminifera, Marine Micropaleontology, 64(3-4), 141-162, doi: 10.1016/j.marmicro.2007.04.003.

Kullenberg, B. (1952), On the salinity of the water contained in marine sediments. Lacan, F., and C. Jeandel (2005), Neodymium isotopes as a new tool for quantifying exchange fluxes at the continent-ocean interface, Earth and Planetary Science Letters, 232(3-4), 245-257, doi:10.1016/j.eps1.2005.01.004.

Larrasoaña, J. C., A. P. Roberts, and E. J. Rohling (2013), Dynamics of Green Sahara Periods and Their Role in Hominin Evolution, PLoS ONE, 8(10), doi: 10.1371/journal.pone.0076514.

Levitus, S. (1983), Climatological Atlas of the World Ocean, Eos, Transactions American Geophysical Union, 64(49), 962, doi:10.1029/EO064i049p00962-02.

L’Hévéder, B., L. Li, F. Sevault, and S. Somot (2013), Interannual variability of deep Convection in the Northwestern Mediterranean simulated with a coupled AORCM, Climate Dynamics, 41(3-4), 937-960, doi:10.1007/s00382-012-1527-5.

Li, L., A. Casado, L. Congedi, A. Dell'Aquila, C. Dubois, A. Alizade, B. L'Heveder, P. Lionello, F. Sevault, S. Somot, P. Ruti, and M. Zampieri (2012), Modeling of the Mediterranean climate system, in MedCLIVAR book II: Mediterranean climate system, developments in earth envi- ronmental sciences. Elsevier, Amsterdam, edited by P. Lionello, P. Boscolo, and R. Boscolo, chap. 7, Elsevier, Amsterdam.

Ludwig, W., E. Dumont, M. Meybeck, and S. Heussner (2009), River discharges of water and nutrients to the Mediterranean and Black Sea: Major drivers for ecosystem changes 
Paleoceanography and Paleoclimatology. 34(2), 237-251, https://doi.org/10.1029/2019PA003566

656

657

658

659

660

661

662

663

664

665

666

667

668

669

670

671

672

673

674

675

676

677

678

679

680

681

682

during past and future decades?, Progress in Oceanography, 80(3-4), 199-217, doi: 10.1016/j.pocean.2009.02.001.

Madec, G. (2008), NEMO ocean engine, 27, Note du Pôle de modélisation, Institut PierreSimon Laplace (IPSL), France, No 27, ISSN No 1288-1619.

Marshall, J., and F. Schott (1999), Open-ocean convection : observation, theory, and models,

Rev. Geophys., 37(1), 1-64, doi:10.1029/98RG02739.

Martinez-Ruiz, F., M. Kastner, A. Paytan, M. Ortega-Huertas, and S. Bernasconi (2000), Geochemical evidence for enhanced productivity during S1 sapropel deposition in the eastern Mediterranean, Paleoceanography, 15(2), 200-209, doi:10.1029/1999PA000419.

Meijer, P. T., and H. a. Dijkstra (2009), The response of Mediterranean thermohaline circulation to climate change: a minimal model, Climate of the Past Discussions, 5(3), 1731-1749, doi:10.5194/cpd-5-1731-2009.

Meijer, P. T., and E. Tuenter (2007), The effect of precession-induced changes in the Mediterranean freshwater budget on circulation at shallow and intermediate depth, Journal of Marine Systems, 68(3-4), 349-365, doi:10.1016/j.jmarsys.2007.01.006.

Millot, C. (2013), Levantine Intermediate Water characteristics: an astounding general misunderstanding! (addendum), Scientia Marina, 78(2), 165-171, doi: 10.3989/scimar.04045.30H.

Millot, C., and I. Taupier-Letage (2005), Circulation in the Mediterranean Sea, pp. 29-66, Springer, Berlin, Heidelberg, doi:10.1007/b107143.

Möbius, J., N. Lahajnar, and K. C. Emeis (2010), Diagenetic control of nitrogen isotope ratios in Holocene sapropels and recent sediments from the Eastern Mediterranean Sea, Biogeosciences, 7(11), 3901-3914, doi:10.5194/bg-7-3901-2010.

Myers, P., and E. Rohling (2000), Modeling a 200-Yr interruption of the Holocene sapropel S1, Quaternary Research, 104, 98-104, doi:10.1006/qres.1999.2100. 
Myers, P., K. Haines, and E. J. Rohling (1998), Modeling the paleocirculation of the Mediterranean: The last glacial maximum and the Holocene with emphasis on the formation of sapropel S1, Paleoceanography, 13(6), 586-606, doi:10.1029/98PA02736.

Myers, P. G. (2002), Flux-forced simulations of the paleocirculation of the Mediterranean, Paleoceanography, 17(1), 1-7, doi:10.1029/2000PA000613.

Piotrowski, A. M., S. L. Goldstein, S. R. Hemming, and R. G. Fairbanks (2004), Intensification and variability of ocean thermohaline circulation through the last deglaciation, Earth and Planetary Science Letters, 225(1-2), 205-220, doi:10.1016/j.epsl.2004.06.002.

Rempfer, J., T. F. Stocker, F. Joos, J. C. Dutay, and M. Siddall (2011), Modelling Ndisotopes with a coarse resolution ocean circulation model: Sensitivities to model parameters and source/sink distributions, Geochimica et Cosmochimica Acta, 75(20), 59275950, doi:10.1016/j.gca.2011.07.044.

Revel, M., C. Colin, S. Bernasconi, N. Combourieu-Nebout, E. Ducassou, F. E. Grousset, Y. Rolland, S. Migeon, D. Bosch, P. Brunet, Y. Zhao, and J. Mascle (2014), 21,000 Years of Ethiopian African monsoon variability recorded in sediments of the western Nile deep-sea fan, Regional Environmental Change, 14(5), 1685-1696, doi: 10.1007/s10113-014-0588-x.

Rohling, E., G. Marino, and K. M. Grant (2015), Mediterranean climate and oceanography, and the periodic development of anoxic events (sapropels), Earth-Science Reviews, 143, 62-97, doi:10.1016/j.earscirev.2015.01.008.

Rohling, E. J. (1994), Review and new aspects concerning the formation of eastern Mediterranean sapropels, Marine Geology, 122(1-2), 1-28, doi:10.1016/00253227(94)90202-X.

Rohling, E. J., and F. J. Hilgen (1991), The eastern Mediterranean climate at times of sapropel formation - a review, Geologie en Mijnbouw, 70(3), 253-264. 
Paleoceanography and Paleoclimatology. 34(2), 237-251, https://doi.org/10.1029/2019PA003566

ther deluge: Mediterranean stagnation and sapropel formation, Nature, 295, 1-30, doi: 10.1017/CBO9781107415324.004.

Sachs, J. P., and D. J. Repeta (1999), Oligotrophy and Nitrogen Fixation During Eastern Mediterranean Sapropel Events, Science, 286(5449), 2485 LP - 2488.

Sanchez-Gomez, E., S. Somot, S. A. Josey, C. Dubois, N. Elguindi, and M. Déqué (2011), Evaluation of Mediterranean Sea water and heat budgets simulated by an ensemble of high resolution regional climate models, Climate Dynamics, 37(9-10), 2067-2086, doi: 10.1007/s00382-011-1012-6.

Schmiedl, G., T. Kuhnt, W. Ehrmann, K. C. Emeis, Y. Hamann, U. Kotthoff, P. Dulski, and J. Pross (2010), Climatic forcing of eastern Mediterranean deep-water formation and benthic ecosystems during the past 22000 years, Quaternary Science Reviews, 29(23-24), 3006-3020, doi:10.1016/j.quascirev.2010.07.002.

Scrivner, A. E., D. Vance, and E. J. Rohling (2004), New neodymium isotope data quantify Nile involvement in Mediterranean anoxic episodes, Geology, 32(7), 565-568, doi: 10.1130/G20419.1.

Sepulchre, P., T. Arsouze, Y. Donnadieu, J. C. Dutay, C. Jaramillo, J. Le Bras, E. Martin, C. Montes, and A. J. Waite (2014), Consequences of shoaling of the Central American Seaway determined from modeling Nd isotopes, Paleoceanography, 29(3), 176-189, doi:10.1002/2013PA002501.

Siani, G., M. Magny, M. Paterne, M. Debret, and M. Fontugne (2013), Paleohydrology reconstruction and Holocene climate variability in the South Adriatic Sea, Climate of the Past, 9(1), 499-515, doi:10.5194/cp-9-499-2013.

Somot, S., F. Sevault, and M. Déqué (2006), Transient climate change scenario simulation of the Mediterranean Sea for the twenty-first century using a high-resolution ocean circulation model, Climate Dynamics, 27(7-8), 851-879, doi:10.1007/s00382-0060167-z.

Spivack, A. J., and G. J. Wasserburg (1988), Neodymium isotopic composition of the 
Paleoceanography and Paleoclimatology. 34(2), 237-251, https://doi.org/10.1029/2019PA003566 Mediterranean outflow and the eastern North Atlantic, Geochimica et Cosmochimica Acta, 52(12), 2767-2773, doi:10.1016/0016-7037(88)90144-5.

Stratford, K., R. G. Williams, and P. G. Myers (2000), Impact of the circulation on sapropel formation in the eastern Mediterranean, Marine Geology, 14(2), 683-695, doi: 10.1029/1999GB001157.

Suc, J.-P. (1984), Origin and evolution of the Mediterranean vegetation and climate in Europe, Nature, 307, 429-432, doi:10.1038/307429a0.

Tachikawa, K., M. Roy-Barman, A. Michard, D. Thouron, D. Yeghicheyan, and C. Jeandel (2004), Neodymium isotopes in the Mediterranean Sea: Comparison between seawater and sediment signals, Geochimica et Cosmochimica Acta, 68(14), 3095-3106, doi: 10.1016/j.gca.2004.01.024.

Tachikawa, K., L. Vidal, M. Cornuault, M. Garcia, A. Pothin, C. Sonzogni, E. Bard, G. Menot, and M. Revel (2015), Eastern Mediterranean Sea circulation inferred from the conditions of S1 sapropel deposition, Climate of the Past, 11(6), 855-867, doi: $10.5194 / \mathrm{cp}-11-855-2015$.

Vance, D., A. E. Scrivner, P. Beney, M. Staubwasser, G. M. Henderson, and N. C. Slowey (2004), The use of foraminifera as a record of the past neodymium isotope composition of seawater, Paleoceanography, 19(2), 1-17, doi:10.1029/2003PA000957.

Vorosmarty, C., B. Feteke, and B. Tucker (1998), Global River Discharge, 1807-1991, V. 1.1 (RivDIS). 